\title{
Grapevine Crown Gall Suppression Using Biological Control and Genetic Engineering: A Review of Recent Research
}

\author{
Attila Filo, ${ }^{1}$ Paolo Sabbatini, ${ }^{1 *}$ George W. Sundin, ${ }^{2}$ Thomas J. Zabadal, ${ }^{1}$ \\ Gene R. Safir, ${ }^{2}$ and Peter S. Cousins ${ }^{3}$
}

\begin{abstract}
Crown gall is a devastating grapevine disease often encountered in vineyards prone to winter cold injury. Agrobacterium vitis, the predominant causal agent of this disease, moves from the roots via xylem sap flow to freeze injury sites where genetic transformations then occur. Crown gall disrupts the grapevine trunk vascular system, which prevents nutrient flow and leads to plant decline and death. Viticultural practices designed to fight this disease are only partially effective, thereby requiring alternatives. Genetic engineering and biological control could be more desirable approaches for disease prevention. Biological control typically involves antagonistic organisms, which are applied to grapevine roots to reduce the concentration of pathogenic Agrobacterium strains. Genetic engineering may prevent infection and tumor formation by modifying grapevines and antagonistic organisms. In the grapevine, this may be achieved by enhancing molecular mechanisms for producing bacterium-specific antimicrobial peptides or preventing transferred deoxyribonucleic acid export, integration, and oncogene expression. Alteration of antagonistic organisms enhances the production of bacteriocins effective against agrobacteria. This article reviews the potential use of biological control options and genetic engineering tools for grapevine crown gall suppression and makes recommendations for further use and research.
\end{abstract}

Key words: Agrobacterium vitis, crown gall, control, biological technology, molecular biology

\section{Crown Gall on Grape and Agrobacterium Nomenclature}

The unchecked growth of tumors on grape, commonly known as crown gall (CG), is one of the most economically destructive diseases in temperate zone viticulture. The chief disease agent is the bacterium Agrobacterium vitis, although other Agrobacterium species may also cause CG on grapevine (Szegedi et al. 2005, Kawaguchi and Inoue 2009). Crown gall results in yield reductions, grapevine decline, and vine death (Süle and Burr 1998). It occurs worldwide and varies by viticultural regions, with the most severe impact in temperate climates. The world map of the Köppen-Geiger on climate classification (Kottek et al. 2006) indicates that grapevine $\mathrm{CG}$ disease occurs in climate regions coded with $\mathrm{Dfb}\left(\mathrm{Tmin} \leq-3^{\circ} \mathrm{C}\right)$. Severe $\mathrm{CG}$ incidences are common in the Great Lakes Region, the Canadian province of Ontario, and

${ }^{1}$ Department of Horticulture, Michigan State University, East Lansing, MI 48824; ${ }^{2}$ Department of Plant Pathology, Michigan State University, East Lansing, MI 48824; and ${ }^{3}$ USDA-ARS, Grape Genetics Research Unit, 630 W. North Street, Geneva, NY 14456.

*Corresponding author (email: sabbatin@msu.edu; fax: 517 353-0890)

Acknowledgments: This work was partially supported by the O'Keefe Research Fund in the Department of Horticulture, Michigan State University.

The authors thank T.J. Burr and J.E. Creasap (Cornell University) for valuable information on viticulture research on crown gall and L.W. Stobbs (Agriculture and Agri-Food Canada) for the photographs of grapevine crown gall. This manuscript was in partial fulfillment of requirements for the master of science degree for A. Filo in the Department of Horticulture, Michigan State University. Manuscript submitted Feb 2012, revised Jul 2012, accepted Sept 2012. Publication costs of this article defrayed in part by page fees.

Copyright (C) 2013 by the American Society for Enology and Viticulture. All rights reserved.

doi: 10.5344/ajev.2012.12038
Germany, Hungary, Slovakia, and the Czech Republic. The economic impact of $\mathrm{CG}$ varies significantly depending upon region. For example, in the state of Pennsylvania, losses were estimated over a six-year period at US $\$ 46,500$ per 0.4 hectare vineyard (Steward and Wenner 2004).

Numerous taxonomic schemes have been proposed for the nomenclature of the Agrobacterium species (Sawada et al. 1993, Willems and Collins 1993, de Lajudie et al. 1998). Nomenclature in this review refers to the system proposed by Kerr and Panagopoulos (1977) and Ophel and Kerr (1990). Kerr and Panagopoulos (1977) demonstrated that grapevine Agrobacterium isolates form a distinct group and differ from strains isolated from other plants. They classified Agrobacterium spp. into three groups: biotype-1, biotype-2, and biotype-3. Ophel and Kerr (1990) demonstrated, through biochemical tests and differential levels of deoxyribonucleic acid (DNA) binding, phenotypic differences between the grapevine Agrobacterium isolates and the previously described $A$. tumefaciens, A. radiobacter, A. rhizogenes, and A. rubi spp. They proposed that grapevine biotype-3 isolates form a new separate Agrobacterium sp. named A. vitis. Based on comparative $16 \mathrm{~S}$ rDNA sequencing, renaming of agrobacteria to Rhizobium radiobacter, $R$. rhizogenes, $R$. rubi, $R$. undicola, and $R$. vitis was proposed (Young et al. 2001, Willems 2006). Currently, the most commonly used nomenclature refers to biotype-1, biotype-2, and biotype-3 strains of Agrobacterium as A. tumefaciens, A. rhizogenes, and A. vitis, respectively. Tumorigenic Agrobacterium spp. are also classified according to the type of their CG tumor-inducing or root-inducing ( $\mathrm{Ti} / \mathrm{Ri}$ ) plasmid, which determines the type of opine(s) synthesized and metabolized by each strain (Paulus et al. 1989, Otten et al. 1996). Classification of Agrobacterium strains by opine production is problematic because of unknown or nonexisting opine types

Am. J. Enol. Vitic. 64:1 (2013) 
of several Ti/Ri plasmid-induced tumors. Moreover, a single plasmid does not always induce only one specific opine type. In fact, inductions of several opine types in various combinations are most often associated with a single Ti/Ri plasmid (Paulus et al. 1989, Otten et al. 1996). Agrobacterium grapevine isolates predominantly metabolize nopaline, vitopine, or octopine/cucumopine and rarely other opine types (Otten et al. 1996). Eleven opine types (octopine, nopaline, succinamopine, agropine, agropine/mannopine, mannopine, chrysopine/succinamopine, chrysopine/nopaline, cucumopine/mikimopine, octopine/cucumopine, and vitopine) are currently being classified (Petit et al. 1983, Szegedi et al. 1988, Dessaux et al. 1998, Pionnat et al. 1999, Moriguchi et al. 2001).

\section{Agrobacterium Ecology and Etiology}

Etiology. Agrobacteria commonly inhabit soils and roots of susceptible host plants (Figure 1). Agrobacterium vitis survives in grapevine plant material, including roots, trunks, cordons, canes, cuttings, and debris, and in vineyard soil. Agrobacteria are generally harmless to plants. However, they can cause a disease if they possess a large ( 200 to 800 kilobase pairs in size; Gelvin 2003) Ti or Ri plasmid. Crown gall is triggered by the integration of transferred-DNA (T-DNA) into the plant nuclear genome and the expression T-DNA genes encoding enzymes of plant hormone biosynthesis. Only the T-DNA, that is only a segment of the Ti plasmid, is transferred into the plant nuclear genome. It is this Ti plasmid that contains the T-DNA and the genes required for its export, integration, and oncogene expression (van Larebeke et al. 1974, De Cleene and De Ley 1976, Portier et al. 2006).

The infection process. Crown gall infection is a threestep process. In step one the pathogen enters the apoplastic space of the plant. Agrobacterium vitis is particularly concentrated in the rhizosphere of grapevines and most commonly infects through roots and underground wound sites (Süle et al. 1995, Burr et al. 1998). Step two centers on the colonization of the xylem by the bacteria. Agrobacterium vitis systemically colonize grapevines and disseminate to shoots via xylem sap flow (Szegedi and Bottka 2002, Szegedi and Dula 2006). The pathogen survives and persists in apparently healthy cuttings for extended periods (Lehoczky 1968, 1971, 1978, 1989, Burr and Katz 1984, Burr et al. 1987, 1988). Step three involves the evasion of plant reactions and suppression of plant defense mechanisms. A well-known example of such mechanism of evasion is the degradation of hydrogen peroxide by the bacterium's catalase enzyme encoded by the katA gene (Xu and Pan 2000).

T-DNA export to plant cell. Wound healing processes, such as callus formation, development of graft union vascular connection, and tissue repair and remodeling in response to grafting and freeze injury, as well as physical damages caused by vineyard equipment, involve cell division and render grapevine cells competent to Agrobacterium transformation. Consequently, these are the primary sites for CG development (Creasap et al. 2005, Otten et al. 2008). The tumorous growth typically occurs around the graft union (Figure 2), on the lower trunk (Figure 3), and at the base and disbudded points of cuttings, as those are prevalent sites of wound healing and highly susceptible to T-DNA export. Many proteins encoded by virulence (vir) genes play essential roles in the T-DNA transfer process. Nearly all proteins encoded by the vir region of the Ti plasmid are required for T-DNA transfer to occur (Burr and Otten 1999, Gelvin 2003, Matthysse 2006, Otten et al. 2008). VirA and VirG form a

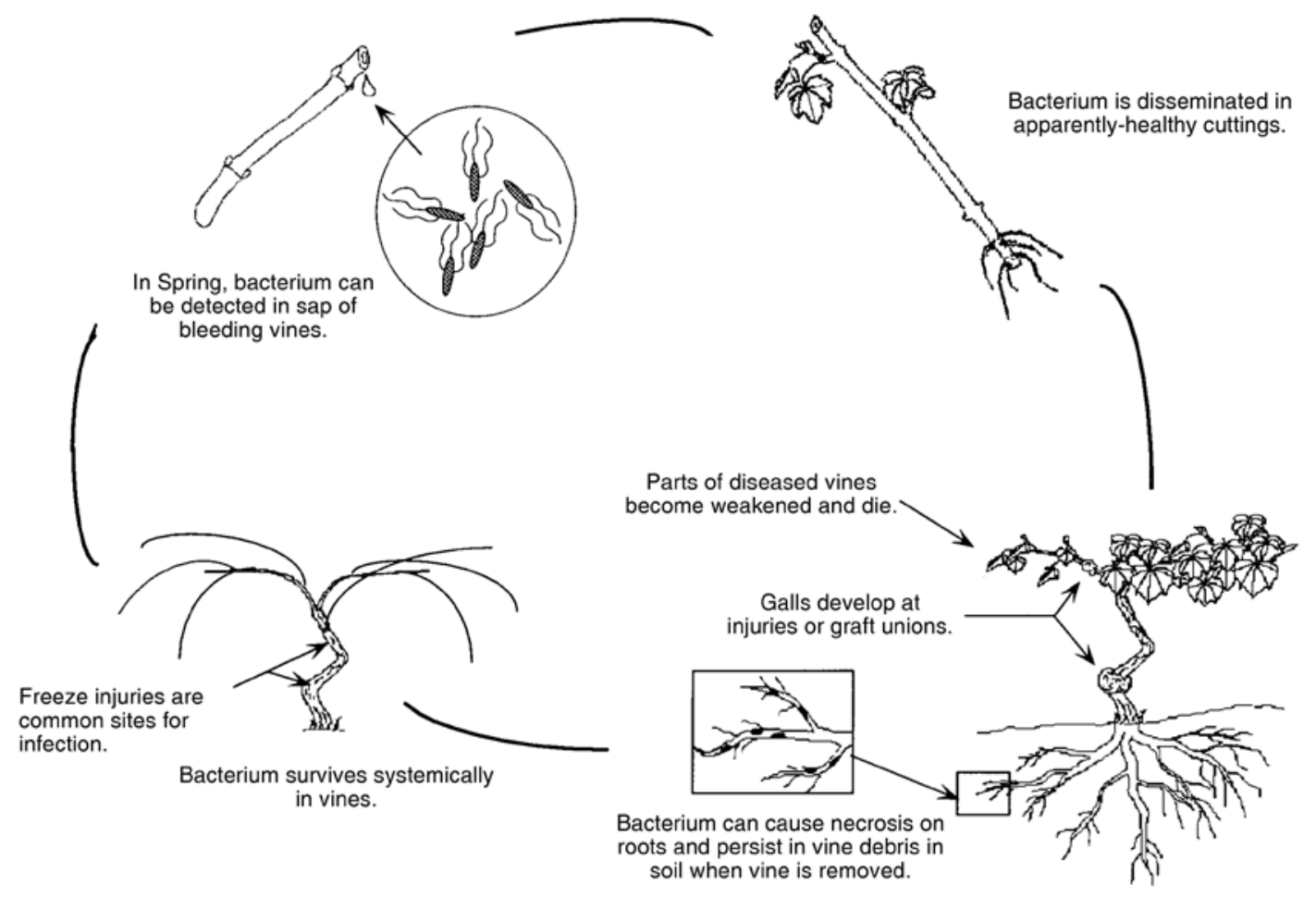

Figure 1 Disease cycle of grapevine crown gall (from Burr et al. 1998; reprinted by permission; @ 1998 American Phytopathological Society). 
two-component regulatory system. VirA works as sensor, while VirG works as transcriptional regulator. VirA senses the presence of specific plant phenolic compounds induced at wound healing, while VirG increases the level of vir gene transcription. VirD4 and VirB proteins are necessary for the transfer of the T-DNA and other Vir proteins. VirD2 serves as a pilot protein that guides the T-DNA through the transfer process, while VirE2 is required for efficient tumor formation. A detailed account of the T-DNA transfer process and the role of individual Vir proteins are provided in a recent review (Lacroix et al. 2008).
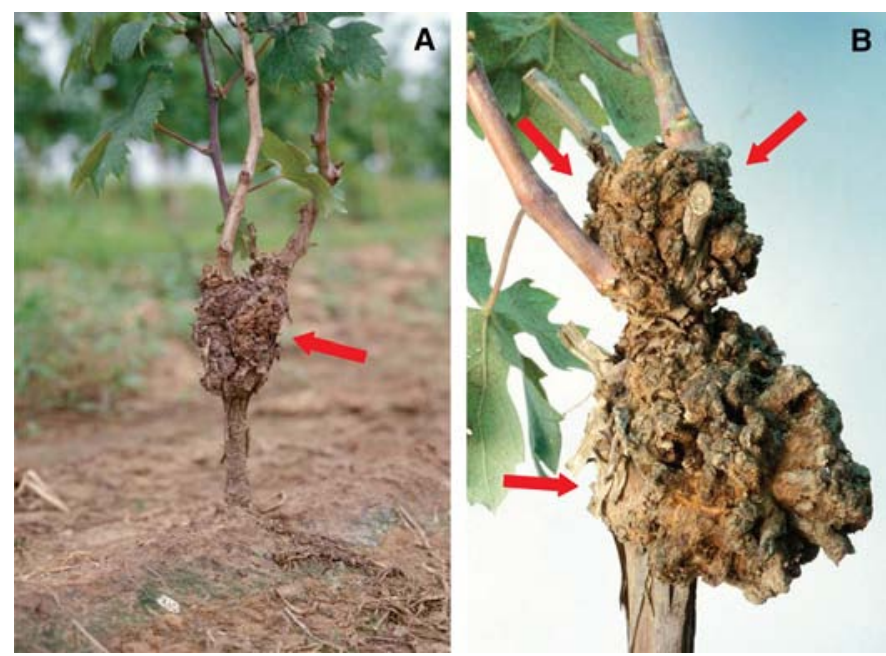

Figure 2 Graft unions of Zinfandel grapevines exhibited crown gall shortly after vineyard establishment in the Canadian province of Ontario. Both vines will inevitably die. Crown gall developed at (A) the upper trunk, including the entire scion, and (B) wound sites around the graft union and the base of the shoots (red arrows).

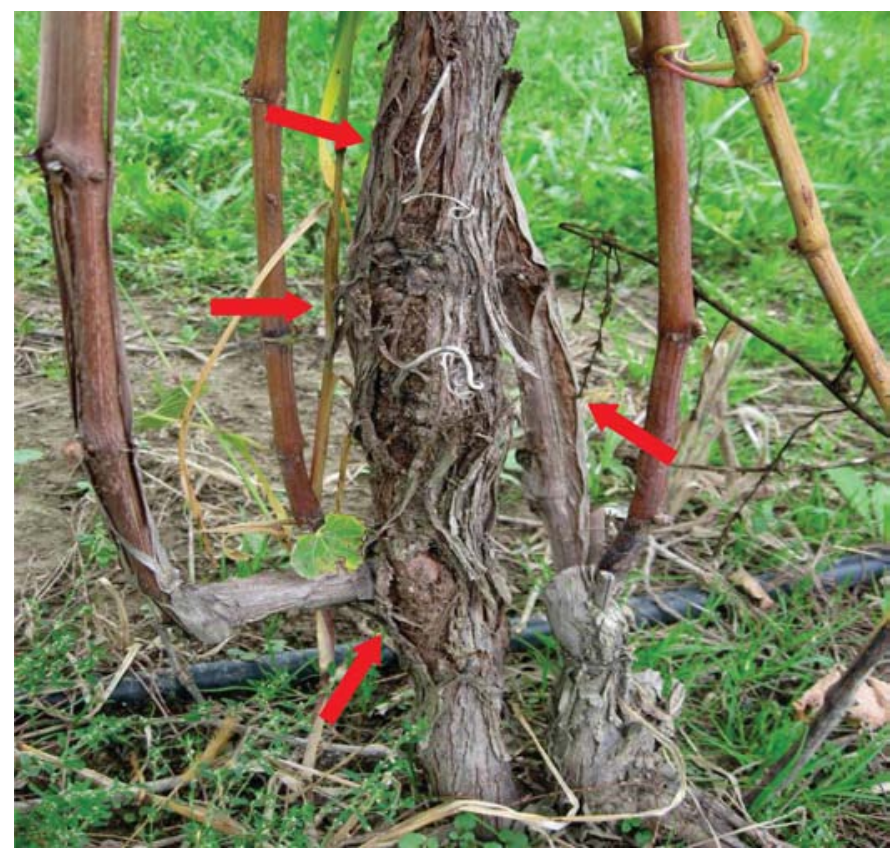

Figure 3 Own-rooted Cayuga White grapevine exhibits crown gall (red arrows). Photo taken at the Horticulture Teaching and Research Center of Michigan State University (East Lansing). The use of multiple trunks helps to reduce the impact of the disease on the entire vine.
T-DNA integration into the plant nuclear genome. Induction of CG formation is unique because it involves the interkingdom transfer of T-DNA from the bacterial pathogen into the plant nuclear genome (Zupan and Zambryski 1995). The bacterial T-DNA is integrated into the plant chromosome where the genetic transformation of the plant cell then begins. Plant cell transformation leads to elevated levels of indole3 -acetic acid (auxin or IAA) and cytokinin production (Morris 1986). Expression of two oncogenes (iaaM and iaaH) was required for auxin synthesis and tumor induction in grapevines (Thomashow et al. 1986, Huss et al. 1990). Auxin is synthesized in a two-step biochemical pathway. Step one includes the expression of the iaaM gene, which induces tryptophan mono-oxygenase production. Tryptophan mono-oxygenase then converts tryptophan to indoleacetamide. Step two involves indoleacetamide hydrolase production by the iaaH gene. Indoleacetamide hydrolase then converts indoleacetamide to auxin (Thomashow et al. 1986, Huss et al. 1990). Interestingly, most $A$. vitis strains only encode auxin synthesis in their TDNA (Fournier et al. 1994). The expression of T-DNA genes within the plant cell and the elevated level of hormone production break the regulation of the cell cycle because the plant cell cannot regulate the expression of the T-DNA genes. These trigger the transformation and abnormal proliferation of plant cells resulting in CG tumor or hairy root formation (Petersen et al. 1989, Gaudin et al. 1994, Costacurta and Vanderleyden 1995).

\section{Management of Grapevine Crown Gall}

Traditional viticultural practices. There are no current completely effective methods of controlling CG disease in nurseries and vineyards. The stage is often set for CG during in-nursery callusing and rooting or after the first winter in the vineyard, generating problems during vineyard establishment (Figure 4). Prevention of freeze injury (selecting

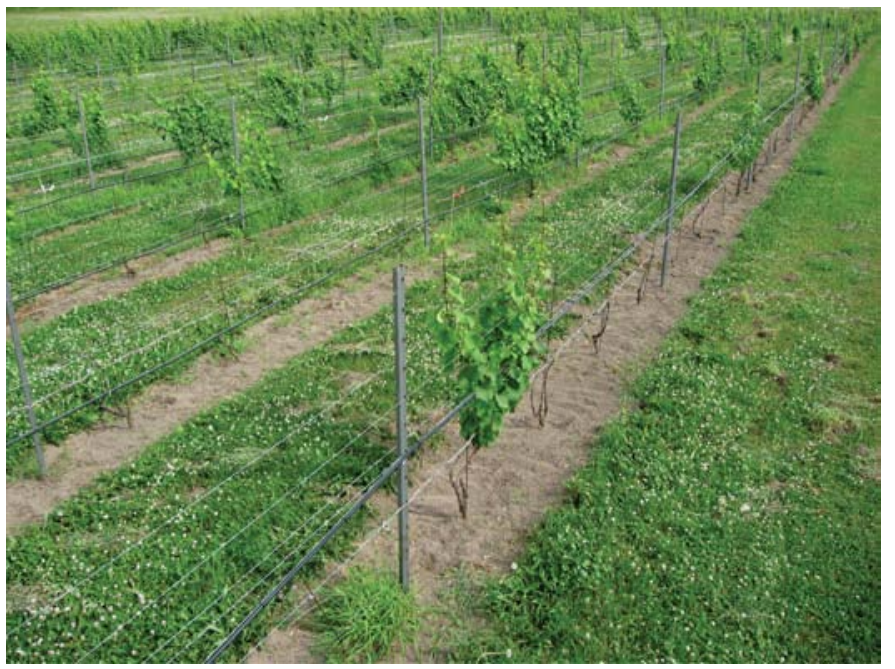

Figure 4 Severe crown gall (CG) incidence and consequently grapevine mortality in a 3-year-old vineyard planted with Riesling (clone 239) vines grafted to Couderc 3309 or Millardet et de Grasset 101-14 rootstocks. Photo taken at Chateau Grand Traverse vineyard (Old Mission Peninsula, Michigan) on 11 July 2010. In April 2010, 1776 of 3077 vines (57.7\%) exhibited CG and 525 of those $1776(29.6 \%)$ did not exhibit any growth during the summer. 
vineyard sites that avoid low temperatures), graft union protection (through soil burial/mulching techniques), frequent trunk renewal (Figure 3), and removal of infected vine parts are major viticulture strategies to suppress CG; however, they are only partially effective (Zabadal et al. 2007). Prevention of infection is a critical disease management strategy. This involves producing pathogen-free planting material by in vitro apical meristem or shoot-tip tissue culture and inhibiting bacterial infection (soil fumigation and soil solarization) (Burr et al. 1988, Pu and Goodman 1993a, Burr and Otten 1999, Szegedi and Süle 2005, Otten et al. 2008). Other strategies to reduce CG incidence in both vineyard and nursery are heat and chemical treatments (such as hot water submersion and oxyquinoline sulfate treatments) of dormant cuttings prior to grafting (Szegedi 1995, Burr et al. 1996, 1998, Burr and Otten 1999, Otten et al. 2008). Breeding for grapevine CG resistance represents another approach. However, resistant varieties that produce high-quality fruit have not yet been developed (Burr et al. 2003). Cultural practices to reduce $\mathrm{CG}$ incidence also include the use of own-rooted vines, cold-hardy cultivars (such as Frontenac and La Crescent), multiple-trunk training systems (Figure 3), irrigation management to avoid freeze injury (Matthysse 2006), and fumigation and solarization to reduce Agrobacterium and nematode population density in soil (Süle et al. 1995, Pinkerton et al. 2000). Nematode (Meloidogyne hapla) feeding sites on grapevine roots may serve as an entry point for A. vitis (Süle et al. 1995). Despite the multiple strategies, none of the currently available cultural practices provide acceptable levels of CG control in temperate viticultural regions.

Novel approaches. The increasing global demand for disease-resistant and stress-tolerant grapevines has prompted significant interest in research into genetic engineering-assisted grapevine breeding. Genetic engineering, also called genetic modification, uses recombinant nucleic acid techniques involving the formation of new combinations of genetic material. This material is produced by inserting externally produced nucleic acid molecules into a virus, bacterial plasmid, or other vector system and then incorporating that vector into a host organism in which they do not naturally occur but in which they are capable of continued propagation (Sands and Galizzi 2006). Organisms derived through genetic engineering are referred to as genetically engineered (GE), genetically modified (GM), and/or transgenic (TG) organisms. For sake of clarity, this review adheres to the most commonly used acronym and refers to such organisms as GM. This approach to genetic engineering-assisted grapevine breeding uses the natural ability of numerous $A$. tumefaciens and A. rhizogenes spp. to transfer DNA interkingdom. The refinement of this technique has impacted plant science, led to rapid progress in plant molecular biology, and has now become the essential embodiment of today's crop biotechnology.

This same characteristic of Agrobacterium is used in efforts to suppress CG disease in viticulture. Research that addresses the development of CG-resistant grapevines through genetic engineering, predominantly for less cold-hardy varieties (Vitis vinifera L.), emerged in the 21st century. Grapevine
CG resistance has been hypothesized to be related to a single gene (Szegedi et al. 1984, Szegedi and Kozma 1984). Research in this era targeted the introduction and expression of foreign genes, the efficacious regeneration of transformed grapevines, and the efficiency of the transformation process (Nakano et al. 1994, Scorza et al. 1996, Mozsár et al. 1998, Torregrosa et al. 2002, Oláh et al. 2003). Deoxyribonucleic acid fingerprint comparisons conducted on ancestral forms of $A$. vitis aimed to provide information on the evolution of the pathogen (Argun et al. 2002). After overcoming the technological hurdles of grapevine transformation, more recent studies addressed specific problems, such as stress tolerance and disease resistance in grapevines (Burr and Otten 1999, Otten et al. 2008).

Efforts to engineer CG resistance into grapevines have focused on three main approaches: blocking infection by expressing antimicrobial peptides in GM plants inhibitory to $A$. vitis; blocking T-DNA export and/or integration; and blocking T-DNA oncogene expression following its export and integration. Genetic engineering may create GM grapevines with resistance to $\mathrm{CG}$ and GM biological control agents (BCAs) with higher CG control efficacy.

A biological control approach for CG disease caused by $A$. tumefaciens depends on the use of a nonpathogenic biological control strain $A$. radiobacter $\mathrm{K} 84$. This strain produces the bacteriocin agrocin 84 which is toxic to certain strains of $A$. tumefaciens and A. rhizogenes (Kerr and Htay 1974, Kim et al. 2006). The mode of action of agrocin 84 is based on the agrocinopine (an analog of agrocin 84 ) biosynthesis by the plant and its catabolism by pathogenic $A$. vitis strains (Kim et al. 2006). Application of strain K84 results in agrocin 84 production by the $\mathrm{K} 84$ strain and agrocinopine biosynthesis by the plant. The Ti plasmid genes of agrocin 84 -sensitive tumorigenic strains encode for agrocinopine uptake and catabolism. This agrocinopine-utilization system enables those strains to take up agrocin 84 . Once taken up, agrocin 84 is toxic to the bacterial cell (Kim et al. 2006). Unfortunately, strain K84 will not control grapevine CG caused by A. vitis (Staphorst et al. 1985, Chen and Xiang 1986, Webster et al. 1986). However, the effectiveness of this BCA in controlling A. tumefaciens-mediated CG suggests that biological control is a viable tool if an effective strain is found.

Biological control strategies to prevent infection. One of the most promising grape CG control technologies is biological control, and it has been defined in many ways. This review adheres to the definition of plant disease biological control as the control of a plant disease with a natural biological process or the product of a natural biological process, including biological chemicals extracted from and delivered by living organisms and constitutive and elicited host resistances (Wilson 1997). This definition allows clear dissociation from other means of plant disease control, such as physical, cultural, synthetic chemical, or genetic engineering-assisted control. Research efforts to discover or develop living organisms, or products created by those organisms, for grapevine CG suppression were initiated in 1972 (Kerr 1972).

The remarkable success of $A$. radiobacter strain K84 represents one of the most exhaustively researched and 
commercially widely used antagonistic microorganisms (Cooksey and Moore 1982, du Plessis et al. 1985, Farrand et al. 1985, Donner et al. 1993, Vicedo et al. 1993, Peñalver et al. 2000). Effective CG control by the $A$. radiobacter strain was demonstrated on several plants, including Prunus, Rubus, Malus, Salix, Libocedrus, Chrysanthemum, Crategus, Carya, Rosa, Pyrus, and Humulus spp. (Moore and Warren 1979). Unfortunately, strain K84 failed to control grapevine CG caused by $A$. vitis (Staphorst et al. 1985, Chen and Xiang 1986, Webster et al. 1986). Consequently, many alternative bacterial strains have now been studied for their ability to inhibit grapevine $\mathrm{CG}$ infection and formation with mixed results. We have included a summary of the most important strains (Table 1) and their relevant characteristics (Table 2).

A. radiobacter strains MI15 and HLB-2. One of the BCAs proved to be effective against $A$. vitis strains was isolated from grapevines (Xuemei et al. 1993). The agrocinproducing $A$. radiobacter strain MI5 (isolated from CG on Muscat Hamburg) inhibited tumor formation caused by $\mathrm{A}$. vitis strains in vitro and on inoculated grapevine shoots. Colonization of wound sites on grapevine stems by $A$. radiobacter strain MI15 was also reported (Xuemei et al. 1993). In another experiment, the $A$. radiobacter strain HLB-2 inhibited CG formation on inoculated young grapevine shoots (Chen and Xiang 1986). In vitro growth of $A$. vitis strains harboring the nopaline or octopine plasmid was inhibited by co-inoculations (Chen and Xiang 1986).
Further research on $A$. radiobacter strain HLB-2 demonstrated suppression of grapevine $\mathrm{CG}$ caused by $A$. vitis strains Ag57, Ag63R, and G-1 (Pu and Goodman 1993b). Seven additional strains of Agrobacterium spp. also showed sensitivity to $A$. radiobacter strain HLB-2. Greatest suppression was achieved when $A$. radiobacter strain HLB-2 was applied at 10,000 times higher concentration than the tumorigenic $A$. vitis strain Ag63R. In this case, 87\% of inoculated grapevine stems did not exhibit tumor symptoms. When the same Agrobacterium strains were co-inoculated with equal or lower concentrations of $A$. radiobacter strain HLB-2, 35 and $0 \%$ of co-inoculated grapevine stems remained symptomless, respectively (Pu and Goodman 1993b).

Dipping of grapevine roots with $A$. radiobacter strain HLB-2 just prior to planting into Agrobacterium-infested soil prevented CG formation ( $\mathrm{Pu}$ and Goodman 1993a). Thirtyfour months after planting, $100 \%$ of the Catawba, Seyval blanc, and Vidal blanc and $78 \%$ of the Chancellor root-treated grapevines had no CG symptoms. Twenty percent of the untreated Catawba and Vidal blanc and $100 \%$ of the untreated Chancellor had CGs (Pu and Goodman 1993a).

Strain HLB-2 reduced internal populations of $A$. vitis, thus promoting grapevine vitality and increasing graft take (Bazzi et al. 1999). Internal populations of $A$. vitis strain CG49 were reduced from $\sim 1.0 \times 10^{9}$ to $7.35 \times 10^{6}$ colony-forming units per $\mathrm{mL}(\mathrm{cfu} / \mathrm{mL})$ following HLB-2 treatment. Less than half the HLB-2 inoculated grapevines were dead or unmarketable

Table 1 List of selected bacterial spp. strains examined for biological control against grapevine crown gall and their relevant characteristics.

\begin{tabular}{|c|c|c|c|}
\hline Bacterial spp. & Strain & Relevant characteristics & References \\
\hline $\begin{array}{l}\text { Agrobacterium } \\
\text { radiobacter }\end{array}$ & HLB-2 & $\begin{array}{l}\text { Inhibits CG formation on inoculated grapevine } \\
\text { shoots. Root treatments prevent CG formation. }\end{array}$ & $\begin{array}{l}\text { Pu and Goodman 1993a, 1993b, Bazzi et al. } \\
1999\end{array}$ \\
\hline A. radiobacter & K84 & $\begin{array}{l}\text { Reported ineffective against } A \text {. vitis strains. One } \\
\text { contradictory report indicated inhibition of a few } \\
A \text {. vitis strains in vitro. }\end{array}$ & $\begin{array}{l}\text { Kerr and Htay 1974, Moore and Warren 1979, } \\
\text { Donner et al. 1993, Vicedo et al. } 1993\end{array}$ \\
\hline A. radiobacter & M115 & $\begin{array}{l}\text { Inhibits in vitro growth and tumor formation caused } \\
\text { by Agrobacterium biotype- } 3 \text { strains. Effective } \\
\text { colonizer of wound sites on grape stems. }\end{array}$ & Xuemei et al. 1993 \\
\hline A. tumefaciens & J73 & $\begin{array}{l}\text { Agrocin-producing strain with broad spectrum activity } \\
\text { against } A \text {. vitis and } A \text {. tumefaciens. }\end{array}$ & Thomson 1986, Webster et al. 1986 \\
\hline A. vitis & E26 & In vitro and in vivo activity against $A$. vitis strains. & $\begin{array}{l}\text { Liang et al. 2001, Li et al. 2005, Wang et al. } \\
\text { 2008, Wei et al. } 2009\end{array}$ \\
\hline A. vitis & $\mathrm{F} 2$ & $\begin{array}{l}\text { Nontumorigenic on grapevines. Effective against } \\
\text { grape CG caused by agrocin and non-agrocin } \\
\text { producing } A \text {. vitis. }\end{array}$ & Staphorst et al. 1985 \\
\hline A. vitis & $\mathrm{F} 2 / 5$ & $\begin{array}{l}\text { Nontumorigenic on grapevines. Biological control } \\
\text { is specific to grapevine CG. Inhibits growth of all } \\
\text { A. vitis strains tested. Causes necrosis of treated } \\
\text { grapevine tissues. }\end{array}$ & $\begin{array}{l}\text { Burr and Reid 1994, Burr et al. 1997, 1999, } \\
\text { Bazzi et al. 1999, Szegedi et al. 1999, Zheng } \\
\text { et al. 2003, Creasap et al. 2005, Hao et al. } \\
2005\end{array}$ \\
\hline A. vitis & VAR03-1 & $\begin{array}{l}\text { Highly effective inhibitor of } A \text {. vitis pathogenic } \\
\text { strains in vitro and in vivo. Root colonizer. }\end{array}$ & Kawaguchi et al. 2005, 2007, 2008 \\
\hline $\begin{array}{l}\text { Pseudomonas } \\
\text { aureofaciens }\end{array}$ & B-4117 & $\begin{array}{l}\text { Inhibits CG development if grape cuttings are } \\
\text { submerged in bacterial solution. }\end{array}$ & Khmel et al. 1998 \\
\hline P. fluorescens & CR330D & Reduces CG incidence and inhibits tumor formation. & Khmel et al. 1998 \\
\hline P. fluorescens & $1100-6$ & $\begin{array}{l}\text { Reduces CG incidence and internal populations of } \\
\text { A. vitis. }\end{array}$ & Eastwell et al. 2006 \\
\hline P. corrugata & JC583 & $\begin{array}{l}\text { Varying levels of tumor formation inhibition in } \\
\text { inoculated grapevine. }\end{array}$ & Bell et al. 1995 \\
\hline Rahnella aquatilis & HX2 & $\begin{array}{l}\text { Inhibits CG formation. Effective against a number of } \\
A \text {. vitis strains. Produces an antimicrobial compound. }\end{array}$ & Bell et al. 1995, Chen et al. 2007, 2009 \\
\hline
\end{tabular}


Table 2 In vitro growth, crown gall (CG) formation inhibition, colonization, persistence, and other relevant characteristics of selected bacterial spp. strains effective in biological control against grapevine crown gall.

\section{Bacterial spp.}

strains In vitro growth and CG formation inhibition

A. radiobacter HLB-2 HLB-2

CG did not develop on root-treated vines. $75 \%$ of root-treated Chancellor did not exhibit CG (Pu and Goodman 1993a).

$87 \%$ of treated vines did not exhibit CG

(Pu and Goodman 1993b). $\begin{array}{ll}\text { A. tumefaciens } & \text { Inhibited in vitro growth of } 9 \text { of } 16 \text { Agrobacterium } \\ \text { J73 } & \text { biotype- } 1,11 \text { of } 14 \text { biotype-2, and } 22 \text { of } 27 \text { A. vitis }\end{array}$ J73 strains (Webster et al. 1986). Inhibited in vitro growth of all nopaline, octopine, and agropine type Ti plasmid strains (Webster and Thomson 1988).

\begin{tabular}{ll}
\hline A. vitis & Inhibited in vitro growth of 20 biotype-3 and one \\
E26 & biotype-1 Agrobacterium strains. Inhibited in vivo
\end{tabular} E26 biotype-1 Agrobacterium strains. Inhibited in vivo CG formation of 18 octopine, one nopaline, and one arginine plasmid harboring Agrobacterium biotype-3 strains (Liang et al. 1990a, 1990b). Inhibited in vivo CG formation of all $A$. vitis strains (Liang et al. 2001). Inhibited in vitro growth of 11 of $12 A$. vitis strains (Wang et al. 2003).

A. vitis Inhibited in vitro growth of 17 of 25 non-agrocin

F2 producing biotype-3 strains (Staphorst et al. 1985). Inhibited in vivo CG formation of $12 \mathrm{~A}$. vitis strains (Burr et al. 1999).

\begin{tabular}{ll}
\hline A. vitis & Inhibited in vitro growth of 21 of 25 A. vitis strains. \\
F2/5 & Two of $19 A$. tumefaciens strains showed sensitivity \\
& to F2/5. Reduced $A$. vitis and $A$. tumefaciens tumor \\
& sizes. Number of sites at which CG developed was \\
& not reduced only when $A$. vitis strain CG78 was used \\
& in inoculations (Burr and Reid 1994$).$
\end{tabular}
in inoculations (Burr and Reid 1994).
Colonization, persistence, and other characteristics

Reduced internal $A$. vitis concentration from $\sim 10^{9}$ to $7.35 \mathrm{x}$ $10^{6} \mathrm{cfu} / \mathrm{mL}$ (Bazzi et al. 1999).

Development of Ti plasmid transfer deficient strain J73 accomplished (Webster and Thomson 1988).

Isolated from wound sites 1 month postinoculation (Liang et al. 1990a). $\sim 10^{4}$ cfu per $g$ of dry soil and fresh roots measured at 5 months postplanting. Blocked attachment of tumorigenic $A$. vitis strain K308 to grape stem and seedling root cells (Li et al. 2005). The avsl $l_{E 26}$ mutant strain was as effective in controlling grape CG as the wild-type E26 (Wang et al. 2008).

\begin{abstract}
Caused necrosis of treated grape tissues, which inhibited callus and graft union formation and reduced graft take (Bazzi et al. 1999, Creasap et al. 2005). Biological control by $\mathrm{F} 2 / 5$ not associated with agrocin production and competition for attachment sites or with its tartrate or octopine utilization plasmids. Inhibition or prevention of T-DNA transfer is likely the main factor of its CG control mechanism (Burr et al. 1997, Szegedi et al. 1999). Necrosis induction may be regulated by aviR gene (Zheng et al. 2003). Regulatory role determination of clp genes in strain F2/5 in progress (Burr, personal communication, 2010).
\end{abstract}

\begin{tabular}{|c|c|c|}
\hline $\begin{array}{l}\text { A. vitis } \\
\text { CG1077 } \\
\text { F2/5 }\end{array}$ & $\begin{array}{l}\text { CG1077 inhibited pathogenic } A \text {. vitis more than strain } \\
\text { F2/5 (Burr et al. 1997). Maximum reduction in internal } \\
\text { A. vitis concentration, from } \sim 10^{9} \text { to } 1.24 \times 10^{6} \mathrm{cfu} / \mathrm{mL} \\
\text { by CG1077 (Bazzi et al. 1999). }\end{array}$ & \\
\hline $\begin{array}{l}\text { A. vitis } \\
\text { F2/5 } \\
\text { CG1076 CG1077 } \\
\text { CG1078 CG1079 }\end{array}$ & $\begin{array}{l}\text { Reduced the percentage of sites at which CG } \\
\text { developed by } A \text {. vitis strain K306 or CG } 49 \text { up to } \\
92 \text { and } 100 \% \text {. Reduced gall areas ranged from } 3 \text { to } \\
21 \mathrm{~mm}^{2} \text {. Average tumor areas and sites at which } \\
\text { galls developed for inoculations only with strain } \\
\text { K306 or CG49 were } 140 \text { and } 40 \mathrm{~mm}^{2} \text { and } 95 \text { and } \\
80 \% \text {, respectively (Burr et al. } 1997 \text { ). }\end{array}$ & \\
\hline $\begin{array}{l}\text { A. vitis } \\
\text { F2/5 (pT2TFXK) }\end{array}$ & $\begin{array}{l}\text { Exhibited increased efficacy against all tested } \\
\text { A. vitis strains compared to wild-type F2/5 (Herlache } \\
\text { and Triplett 2002). }\end{array}$ & $\begin{array}{l}\text { Produces trifolitoxin peptide antibiotic (Herlache and Triplett } \\
\text { 2002). }\end{array}$ \\
\hline $\begin{array}{l}\text { A. vitis } \\
\text { VAR03-1 }\end{array}$ & $\begin{array}{l}\text { Inhibited in vitro growth of all tumorigenic } A \text {. vitis } \\
\text { strains (Kawaguchi et al. 2005). Reduced the number } \\
\text { of sites at which CG developed up to } 94.3 \% \\
\text { (Kawaguchi et al. 2005, 2007). Inhibited in vitro } \\
\text { growth of all tested pathogenic Agrobacterium strains. } \\
\text { Inhibition zones ranged up to } 24.5 \mathrm{~mm} \text {. Root treatment } \\
\text { reduced CG incidence up to } 26.7 \% \text { in vivo and } 46.7 \% \\
\text { in the greenhouse (Kawaguchi et al. 2008). }\end{array}$ & $\begin{array}{l}\text { Eighteen months after root submersion treatment, } \\
\text { detectable VAR03-1 ranged from } \sim 10^{6.10} \text { to } 10^{6.28} \mathrm{cfu} / \mathrm{g} \text { fresh } \\
\text { roots (Kawaguchi et al. 2008). }\end{array}$ \\
\hline $\begin{array}{l}\text { P. aureofaciens } \\
\text { B-4117 and } \\
\text { P. fluorescens } \\
\text { CR330D }\end{array}$ & $\begin{array}{l}\text { In vitro growth inhibition zones ranged up to } 14 \text { and } \\
20 \mathrm{~mm} \text { for } A \text {. vitis strain Sz } 1 \text { and Tm } 4 \text {. Reduced } \\
\text { in vivo CG incidence up to } 5 \text {-fold. Reduced in vivo } \\
\text { CG incidence up to } 3.5 \text {-fold } 2 \text { months postplanting } \\
\text { submerged and sprayed vines in the vineyard } \\
\text { (Khmel et al. 1998). }\end{array}$ & $\begin{array}{l}120 \text { days postinoculation, population density declined } \\
\text { from } \sim 10^{9} \text { to } 10^{4} \mathrm{cfu} / \mathrm{g} \text { dry root. The } \sim 10^{4} \mathrm{cfu} / \mathrm{g} \text { dry root } \\
\text { population density remained constant for up to } 1 \text { year. } 24 \\
\text { days postinoculation, the mean colonization level for sterile } \\
\text { and nonsterile soil by the antagonists was } \sim 10^{4} \mathrm{cfu} / \mathrm{g} \text { soil } \\
\text { (Khmel et al. } 1998) \text {. }\end{array}$ \\
\hline $\begin{array}{l}\text { R. aquatilis } \\
\mathrm{HX} 2\end{array}$ & $\begin{array}{l}\text { In vitro inhibition zones of } A \text {. vitis strains ranged up } \\
\text { to } 42.7 \mathrm{~mm} \text {. Eight months after root submersion } \\
\text { treatment, in vivo } \mathrm{CG} \text { incidences were reduced with } \\
62.5,63.8 \text {, and } 61.3 \% \text { (Chen et al. } 2007) \text {. Prevented } \\
\text { CG formation by } A \text {. vitis strain K308 for } 40 \text { days } \\
\text { (Chen et al. 2009). }\end{array}$ & \\
\hline
\end{tabular}


compared to the untreated and controls (Bazzi et al. 1999). Although strain HLB-2 reduced internal $A$. vitis, the magnitude of the reduction cannot ensure prevention of $C G$ incidence in the vineyard.

Results of these experiments (Chen and Xiang 1986, Pu and Goodman 1993a, 1993b, Bazzi et al. 1999) cannot be compared because different treatment methods were used, such as grapevine root versus stem, cutting, or shoot inoculations. Each treatment mode aims to assess the efficacy of select BCAs against pathogenic Agrobacterium strains. However, deployment of BCAs can be accomplished through different plant tissue systems and by various methods, suggesting that efficacy (including colonization and translocation) of BCAs may vary significantly by plant tissue systems and methods for deployment.

A. tumefaciens strain J73. One of the first demonstrations of the biological control potential of grapevine $\mathrm{CG}$, using Agrobacterium strains other than $A$. radiobacter and A. vitis, involved A. tumefaciens strain $\mathrm{J} 73$ (Thomson 1986, Webster et al. 1986). This strain exhibited a broad spectrum of activity against $A$. tumefaciens and $A$. vitis strains in vitro. $\mathrm{J} 73$ was classified as an agrocin-producing biotype-2 strain with a nopaline-type Ti plasmid. A previous experiment (Staphorst et al. 1985) verified sensitivity of four biotype-3 strains to $A$. radiobacter strain K84. However, A. radiobacter strain K84 was effective only against strains harboring nopalinetype Ti plasmids. J73 inhibited all nopaline-, octopine-, and agropine-type Ti plasmid strains (Thomson 1986, Webster et al. 1986).

Strain J73 was pathogenic on a number of plants other than grapevines, which restricted its in vivo use as a BCA for grapevine CG. To prevent potential CG elicitation, it had to be cured of its nopaline-type Ti plasmid to disable the interkingdom transfer of strain J73 T-DNA. This was accomplished by the introduction of selectable plasmids carrying the origins of replication of either the nopaline Ti plasmid, pTiC58, or the octopine Ti plasmid, pTi15955 (Webster and Thomson 1988).

A. vitis strain E26. A nonpathogenic, agrocin-producing, Agrobacterium biotype-3 strain was isolated in 1989 (Liang et al. 1990a). It was originally designated as $A$. radiobacter strain E26 and is now identified as A. vitis strain E26. It was effective in vitro and in vivo against 20 biotype- 3 and one biotype-1 Agrobacterium isolates (Liang et al. 1990a, 1990b). Although inhibition levels were not specified, strain E26 exhibited both in vitro and in vivo inhibition of C58 (biotype-1), K27 (biotype-2), pt12 (biotype-1), A6 (biotype-1), and Bo542 (biotype-2) strains. In vivo inhibition was obtained on 18 octopine, 1 nopaline, and 1 arginin plasmid harboring Agrobacterium biotype-3 strains when grapevine stems were coinoculated with equal concentrations of strain E26. Isolation of strain E26 from wounded sites one month after inoculation verified its ability to colonize grapevine tissues. It was also effective when tested against the Ti-plasmid cured avirulent $A$. tumefaciens strain C58. Liang et al. (1990a, 1990b) concluded that resistance to strain E26 is chromosomally encoded.

When grapevines were inoculated with tumorigenic $A$. vitis strains, CG formation was inhibited in all 12 cases by strain E26 (Liang et al. 2001). Eleven of 12 A. vitis strains showed in vitro sensitivity to strain E26. An agrocin compound designated as Ar26 was isolated and purified from E26. It was effective against $A$. vitis strain MI3-2 (Liang et al. 2001, Wang et al. 2003).

E26 was able to achieve high-efficacy rhizosphere and rhizoplane colonization ( $\mathrm{Li}$ et al. 2005). It was also able to block attachment of the tumorigenic $A$. vitis K308 to grape stem and seedling root cells. The average $10^{4} \mathrm{cfu}$ E26 population per $\mathrm{g}$ of dry soil and fresh roots at 5 months postplanting (Li et al. 2005) also suggests that E26 is suitable for grapevine CG suppression.

Numerous molecular biology studies were done on E26. The role of a LuxR-LuxI type quorum-sensing system involved in the induction of the hypersensitive response (HR) in tobacco by strain E26 was shown (Wang et al. 2008). $\mathrm{AvsI}_{\mathrm{E} 26}$ and $\mathrm{AvsR}_{\mathrm{E} 26}$ components of the wild-type strain E26 are believed to be responsible for long- and short-chain acylhomoserine lactones signal induction required for HR in tobacco. The avsI $I_{E 26}$ mutant was unable to elicit the HR. This proved that the AvsI quorum-sensing system was necessary for induction of the HR. Biological control efficacy of the wild-type E26 and the avsI $I_{E 26}$ mutant strains was not significantly different, as demonstrated in pot trials. Developed galls were very small and their weights, 40 days following inoculation, for grapevines co-inoculated with the pathogenic A. vitis strain $\mathrm{K} 308$ and strain E26 or avsI $I_{E 26}$ mutant strain, were greatly reduced as compared to when only K308 was used as inoculum-negative control (Wang et al. 2008).

A genetic study was undertaken on the vir regions of strain E26 for risk determination of its commercial use as a BCA in field applications (Wei et al. 2009). None of the five (virA, virG, iaaH, iaaM, and ipt) genes required for tumorigenicity were detected by PCR and Southern blot analyses. Lack of virA and virG pathogenic determinants in strain E26 suggests its inability for CG symptom elicitation in both host and nonhost plants (Wei et al. 2009).

A. vitis strain F2. Another $A$. vitis strain, first isolated in South Africa and designated as strain F2, redesignated as A. vitis strain F2/5 by Burr and Reid (1994), was proven to be nontumorigenic on grapevines and effective against grapevine CG (Staphorst et al. 1985, Burr et al. 1999). Using in vitro testing, 17 of 25 serologically different non-agrocinproducing biotype-3 strains showed sensitivity to strain F2. Crown gall formation by 12 biotype- 3 strains was prevented in the greenhouse when co-inoculation of 11 different nonagrocin-producing and four agrocin-producing tumorigenic A. vitis strains was made with strain F2 (Staphorst et al. 1985, Burr et al. 1999).

Burr and Reid (1994) tested A. vitis strain F2/5 against 25 A. vitis and 19 A. tumefaciens strains in vitro and 10 A. vitis and three $A$. tumefaciens on inoculated grapevine trunks. In vitro, $21 \mathrm{~A}$. vitis and two A. tumefaciens (biotype-1) strains exhibited sensitivity to strain F2/5. Greatest efficacy of CG suppression was observed on grapevine trunks when suspensions containing equal concentrations of strain F $2 / 5$ and the pathogen were co-inoculated. Reduction of gall size for seven 
A. vitis and for two A. tumefaciens strains was observed. Only in cases where $A$. vitis strain CG78 was used, no reduction was exhibited in the number of inoculated sites in which galls developed (Burr and Reid 1994).

The protective action of antagonist $A$. vitis strains $\mathrm{F} 2 / 5$, CG1077 (the agrocin-minus mutant of F2/5), CG523, and A. radiobacter strain HLB-2 was tested (Bazzi et al. 1999). Those antagonists were used against the pathogenic $A$. vitis strain CG49. Influences on grapevine vitality, graft take, and wood and root productions were assessed. Eight months posttreatment, callus tissues were collected close to the graft union and subjected to quantitative isolation of $A$. vitis strain CG4. Maximum decrease in the internal concentration of this strain was achieved in grapevines treated with the antagonist F2/5-mutant strain CG1077. Excessive lignification and severe tissue necrosis at both the graft union and vascular parenchyma, throughout the vines treated with the wild-type strain F2/5, were reported. The strain F2/5 treatment significantly reduced graft take (from 97.5 to $67.5 \%$ ) while there was only a slight decrease (from 67.1 to $63.2 \%$ ) for the control. Grapevines treated with the BCAs (other than F2/5) also exhibited fewer necrotic symptoms on woody parenchyma tissues. Bazzi et al. (1999) concluded that establishing vineyards with grapevines containing a high concentration of $A$. vitis may be difficult.

Burr et al. (1997) questioned whether the biological control ability of strain F2/5 is based on agrocin production. Other hypotheses, including competition for attachment sites on grapevine cells and possible prevention of T-DNA transfer by strain F2/5, were also addressed. Chardonnay vines were inoculated with a $1: 1$ ratio of mixed suspensions containing the $A$. vitis strain CG49 and strain F2/5 or its agrocin-minus mutants CG1076, CG1077, CG1078, or CG1079. The number of cells of strain CG49 that attached to grapevine shoot tissues was significantly reduced (from $\sim 10^{5}$ to $10^{4} \mathrm{cfu} / \mathrm{mL}$ ) following co-inoculation with either F2/5 or CG1077 strains. Results confirmed that grapevine CG control by strain F2/5 is not associated with agrocin production or with competition for attachment sites (Burr et al. 1997). Moreover, it is not associated with its tartrate or with octopine utilization plasmids (Szegedi et al. 1999).

Strain F2/5 was GM for trifolitoxin (TFX) peptide antibiotic production (Herlache and Triplett 2002). The strain ( $A$. vitis strain F2/5(pT2TFXK)) exhibited an enhanced level of $\mathrm{CG}$ disease suppression. It contains a plasmid that is encoded for TFX production. Strain F2/5(pT2TFXK) is more effective against all tested $A$. vitis tumorigenic strains than the wild-type F2/5, as well as the TFX nonproducing negative control, F2/5(pT2TX3K). One month after co-inoculation of Nicotiana glauca, with wild-type F2/5 and $A$. vitis strains CG49, CG78, or CG435, gall formation occurred in all plants. However, when co-inoculation was performed in the same manner, but with the GM TFX-producing F2/5(pT2TFXK), gall formation was reduced. In those cases, 10 of 14 (71.4\%), 1 of $8(12.5 \%)$, and 0 of $14(0.0 \%)$ of the inoculants exhibited tumor symptoms, respectively (Herlache and Triplett 2002). The competition of TFX compounds with Agrobacterium and
Rhizobium spp. is likely an important factor of its biological control mechanism (Robleto et al. 1998, Scupham and Triplett 2006). More work is needed to specify TFX mode of action.

Potential negative effects of strain F2/5 on grapevine tissues were previously reported (Bazzi et al. 1999) that include wound healing and graft-take reductions, partial callus formation, excessive lignification, and tissue necrosis in cuttings. Those negative effects were confirmed (Creasap et al. 2005). Necrotic symptoms were observed on cells generated following cambium activation at wounded sites. This necrosis was suggested as a cause for abnormal wound healing and failure of graft union. The necrosis is regulated by expression of a luxR homolog, aviR gene (Zheng et al. 2003, Hao et al. 2005). The exact mode of action by which strain F2/5 controls grape $\mathrm{CG}$ remains unknown.

A. vitis strain VAR03-1. The nonpathogenic $A$. vitis strain VAR03-1 was the most effective strain tested against pathogenic $A$. vitis isolates in several experiments. In the first series of experiments (Kawaguchi et al. 2005), all the 11 tumorigenic A. vitis strains showed in vitro sensitivity to strain VAR03-1. One year after in vivo co-inoculation of Neo Muscat seedling stems, no withered symptoms were observed. In this case, strain VAR03-1 was co-inoculated with the tumorigenic $A$. vitis strain $\mathrm{G}-\mathrm{Ag}-27$. In a separate experiment, significant reduction was achieved (as compared to when only G-Ag-27 was used as inoculum-positive control) in the number of sites at which galls developed. Ten grapevine seedling stems were used for each replication and seven inoculations were made on each stem. Co-inoculations were made with suspensions containing a 1:1 ratio of the pathogenic G-Ag-27 and VAR03-1. Tumor formation reductions (TFRs), measured 12 weeks after inoculation, were from 66 of 70 to 0 of 70 (94.3\% TFR), from 70 of 70 to 23 of 70 (67.1\% TFR), and from 68 of 70 to 10 of 70 (82.9\% TFR) (Kawaguchi et al. 2005).

In the second series of experiments, grape $\mathrm{CG}$ biological control ability of strain VAR03-1 was assessed against $A$. vitis strains $\mathrm{G}-\mathrm{Ag}-27$ and seven other $A$. vitis strains isolated in Japan (Kawaguchi et al. 2007). Inoculation of Neo Muscat cuttings was made with suspensions containing $\sim 10^{8} \mathrm{cfu} / \mathrm{mL}$ of pathogenic inoculant-positive control. Co-inoculation was made with a 1:1 ratio of the pathogenic strain and the BCA VAR03-1. Ten grapevine seedling stems were used for each replication and six inoculations were made on each stem. Twelve weeks after inoculations, CG incidence were reduced from $93.3 \%$ (highest TFR) to $33.3 \%$ (lowest TFR) when the BCA and strain A5-6 or strain A5-1 were used in co-inoculations. Statistically significant reduction in $\mathrm{CG}$ incidence by $A$. vitis strain G-Ag-27 was also reported after grapevine root treatments (Kawaguchi et al. 2007). In the third series of experiments, high efficacy of strain VAR03-1 to control grape CG caused by $A$. vitis strains MAFF 211674, MAFF 211676, At-90-23, and G-Ag-27 was reported (Kawaguchi et al. 2008).

Antagonists outside the genus Agrobacterium. Although the majority of BCAs tested against grape CG belong to the genus Agrobacterium, significant efforts have been made to identify potential biological control organisms outside this genus. In one study, 24 of 851 bacterial isolates exhibited 
activity against $A$. vitis strains (Bell et al. 1995). Biolog identification tests revealed that the few effective isolates were strains of Enterobacter agglomerans, Rahnella aquatilis, and Pseudomonas spp. The most rapid decline of population of $A$. vitis strain AA25 in soil was achieved when soil co-inoculations were made using a 10:1 ratio of AA25 and Pseudomonas corrugata strain JC583. In vitro and in planta, three $P$. corrugata strains exhibited various levels of biological control ability as measured by growth and tumor formation inhibition of tumorigenic A. vitis strains, respectively (Bell et al. 1995).

Pseudomonas spp. strains. Pseudomonas aureofaciens strain B-4117 and P. fluorescens strain CR330D were tested for biological control activity against $A$. vitis strains $\mathrm{Tm} 4$ and Szl (Khmel et al. 1998). The pattern of decline over time in numbers of antagonistic bacteria on grapevine roots was similar for all strains used. Rapid decline was observed 120 days after inoculation and then remained constant for up to one year. When cuttings were treated with antagonists, a decrease in CG incidence and lowered pathogenicity, as shown by reduction in tumor sizes, were observed as compared to water-treated control vines (Khmel et al. 1998).

Rahnella aquatilis strain HX2. Although inhibitory effects of $R$. aquatilis bacteria toward various isolates of $A$. vitis were already reported (Bell et al. 1995), only recently have extensive studies on this potential BCA been initiated. Rahnella aquatilis strain HX2 isolated in China from vineyard soil was shown to be effective against a number of $A$. vitis isolates (Chen et al. 2007). Experiments confirmed the remarkable efficacy of HX2 for short-term CG suppression (Chen et al. 2007). Further biological control assays and characterizations of strain HX2 have also been made (Chen et al. 2009). Analysis of the antimicrobial compound produced by this strain revealed that the compound is likely to be thermostable, contains one or more kind of sugars, is most active against Agrobacterium spp., and inhibits Clavibacter, Pectobacterium, Pseudomonas, and Xanthomonas spp. It was determined that its mode of action does not include bacterial cell lysis or cause cytoplasmic material leakage at minimal inhibitory concentration. Analyses conducted on the impacts of HX2 antimicrobial compound(s) suggested that inhibition of RNA and protein synthesis, required for T-DNA transfer and tumor formation processes, is likely to be the main factor involved in its mode of action (Chen et al. 2009).

Genetic engineering strategies to prevent infection. Several experiments targeted the prevention of grape CG infection by expressing antimicrobial peptides in GM plants inhibitory to A. vitis. Genetically modified Chardonnay grapevines, which possessed either the natural (Mag-2) or the synthetic (MS199) maganin short peptide antimicrobial compound-producing genes, were assayed. Their ability to confer resistance to grape CG (A. vitis) and powdery mildew (Erysiphe necator) was tested (Vidal et al. 2006). The development of strong resistance was not achieved; nonetheless, regenerated lines expressing the Mag-2 or MSI99 genes exhibited significantly less CG incidence than non-GM controls. Enhancement of transgene expression and the spectrum of resistance were suggested to achieve grape $\mathrm{CG}$ and powdery mildew resistance with GM grapevines carrying genes encoded for maganin antimicrobial compound production (Vidal et al. 2006).

Crown gall suppression via GM grapevines carrying the Mag-2 or MSI99 genes was demonstrated (Kikkert et al. 2009). Decreased pathogenicity by reduction in gall sizes was observed on greenhouse-grown maganin-expressing Chardonnay inoculated with A. vitis strain TM4 or CG450. In vitro inhibition of those A. vitis strains by Mag-2 and MSI99 compounds was also reported (Kikkert et al. 2009).

These results suggest the high CG resistance potential of grapevines expressing Mag-2 or MSI99 genes. Increased resistance to CG may be achieved by expressing the Mag-2 or MSI99 peptides in GM grapevines containing truncated vir genes, which may result in antimicrobial activity and inhibition of T-DNA export and integration simultaneously. This multiple inhibition of pathogenic strains may prevent CG formation by simultaneous blocking of the infection and genetic transformation. Therefore, further research with the Mag-2 and MSI99 peptides in GM grapevines is warranted.

Strategies to prevent T-DNA export to plant cell and integration into the plant nuclear genome. High-efficacy CG-resistant GM grapevine generations were confirmed by transferring and expressing the truncated form of the Tiplasmid virE2 gene in grapevine somatic embryos via Agrobacterium-mediated transformation (Krastanova et al. 2010). According to several previous VirE2-involved T-DNA export and integration blocking studies, the increased resistance is believed to be associated with competition of the mutated VirE2 proteins with functional VirE2 proteins. Within the plant cell the competition appears to block the integration of the T-DNA into the plant cell nucleus (Burr and Otten 1999, Gelvin 2003, Matthysse 2006, Otten et al. 2008). The truncated virE2 genes from $A$. tumefaciens strain $\mathrm{C} 58$ and $\mathrm{A} 6$ and $A$. vitis strain CG450 were expressed in Teleki 5C, Richter 110, and Couderc 3309 grapevine rootstocks. The truncated and transferred virE2 genes were present in 314 of 322 (97.5\%) GM lines, confirmed by double antibody sandwich enzymelinked immunosorbent assay (DAS-ELISA), and in 285 of 295 (96.6\%) GM lines, confirmed by polymerase chain reaction (PCR). In vitro susceptibility to Agrobacterium was evaluated 14 and 21 days postinoculation by visual observation of tumor formation on inoculated shoot internodes. Genetically modified plants with no galls or with galls less than $2 \mathrm{~mm}$ diameter on half or less of the total number of explants were scored as resistant. In vitro, shoot internodes of Richter 110 transformed with strain C58-virE2 gene were inoculated with one of three tumorigenic strains: A. tumefaciens C58 (nopaline), A6 (octopine), or $A$. vitis CG450 (vitopine). This resulted in tumor formations being significantly reduced when compared to the non-GM control Richter 110. The highest TFR was achieved when tumorigenic A. tumefaciens strain C58 was used in the inoculations of strain C58-virE2 gene-transformed Richter 110. All of the non-GM control Richter 110 exhibited visible tumors. In vitro, shoot internodes of Teleki 5C, transformed with C58, A6, or CG450-virE2 gene, were inoculated with homologous or heterologous tumorigenic $A$. tumefaciens 
strain C58, A6, or A. vitis strain CG450. As in the case before, tumor formations were reduced significantly when compared to the non-GM control Teleki 5C.

The highest TFRs $(90.0 \%)$, as compared to the non-GM control Teleki 5C (5.0 and 0.0\%), were achieved when tumorigenic $A$. tumefaciens strain C58 or A. vitis strain CG450 was used in the inoculations of strain C58-virE2 or CG450-virE2 gene-transformed Teleki $5 \mathrm{C}$, respectively. In cases of the nonGM control Teleki 5C inoculations, CG developed on 95.0, 94.7, and $100.0 \%$ strain C58, A6, or CG450 inoculated shoot internodes, respectively (Krastanova et al. 2010).

This research confirmed the feasibility of GM rootstock grapevine production using truncated virE2 genes of tumorigenic A. tumefaciens strain C58, A6, and A. vitis CG450. Due to the highest TFR performances exhibited by C58-virE2 gene-transformed vines, the truncated C58-virE2 can be considered one of the most effective genetic resources available for CG-resistant GM grapevine generation. Evaluation of long-term CG resistance of the generated GM vines in vineyard settings and further investigation into the efficacy of truncated virE2 genes of other previously untested Agrobacterium strains are suggested.

The development of CG-resistant Richter 110 rootstock grapevines was achieved by blocking T-DNA integration into the host genome (Holden et al. 2003). Genetically modified grapevines containing the truncated virE2 genes of $A$. tumefaciens strain $\mathrm{C} 58$ or A6 or of $A$. vitis strain CG450 were generated and assessed for CG susceptibility. Seven lines of shoot explants, transformed with the truncated C58-virE2 gene and inoculated with strain C58, expressed resistance. Two of these seven also showed resistance to the other two Agrobacterium strains (Holden et al. 2003).

These results suggest that transformation of grapevines with strain-specific truncated Agrobacterium virE2 genes can result in grapevines expressing resistance to different Agrobacterium biotypes and strains. As reported by Krastanova et al. (2010), this experiment confirmed the importance of truncated virE2 gene of A. tumefaciens strain C58 in CGresistant grapevine generation.

A total of 928 putative GM grapevine combinations were generated (Xue et al. 1999) and tested for resistance to grape CG, grapevine fanleaf virus (GFLV), and grapevine leafrollassociated closterovirus-3 (GLRaV-3). Transformed vines contained a sense-oriented translatable gene of GFLV, an antisense coat protein gene of truncated HSP90-related (heatshock protein 90) gene of GLRaV-3, and a virE2 of B gene (a truncated virE2 that lacks 215 carboxyl-terminal amino acids; Citovsky et al. 1994) from A. tumefaciens strain C58. Transformation efficiency of the five grape rootstocks with seven gene constructs varied. Rates of transformation ranged from 45 to $100 \%$. Transgenes were present in each case as determined by PCR or Southern Blot analysis. Disease and virus resistance evaluations of the GM vines are in progress (Xue et al. 1999).

Strategies to prevent expression of T-DNA oncogenes. Transferred-DNA oncogene expression prevention (often referred to as "gene silencing"), using RNAi technology, in- volves within-plant cell expression of messenger ribonucleic acid (mRNA) complementary to the mRNA of a gene whose expression inhibition is targeted. Expression inhibition of a gene is accomplished through 21 to 25 nucleotides-long RNA species (RNAs) that are derived to become RNA-induced gene silencing (Agrawal et al. 2003). The use of RNAs leads to the degradation of targeted RNA to nucleotides resulting in T-DNA oncogene expression prevention. Efficacy of gene silencing for high-level CG resistance was confirmed by several research experiments (Ebinuma et al. 1997, Escobar et al. 2001, Kovács et al. 2003, Lee et al. 2003).

Feasibility of silencing the expression of an $A$. vitis oncogene, thus preventing tumor formation, has been investigated (Kovács et al. 2003). The study demonstrated oncogene silencing in GM Petunia hybrida containing double-transformed 35S-iaaM gene. One line of those transformed plants exhibited reduced iaaM RNA levels; however, it failed to attenuate tumorigenesis when challenged with $A$. vitis isolates. A possible explanation for this phenomenon is that the $35 \mathrm{~S}$ iaaM transgene may have produced a chimeric RNA molecule that was unable to induce silencing of the $A$. vitis iaaM gene (Kovács et al. 2003, Kovács, personal communication, 2009). It was demonstrated that the iaaM silencing construct must contain the translation start site of the gene's sense strand in order for silencing to be effective (Lee et al. 2003).

\section{Conclusion}

Whether biological control using natural bacterial strains, biological control by genetically modified antagonistic strains, or genetic engineering of grapevines will lead to control of grape CG disease is still under investigation. Despite current limitations, biological control appears to have the greatest probability for success in grapevine CG control. Moreover, it shall likely prove to be the most palatable strategy for consumers, which would expectedly drive the preference of the industry accordingly. The genetic diversity of Agrobacterium grapevine isolates is considered the major limitation for successful biological control. For example, diversity in the $A$. vitis population could affect susceptibility to bacteriocins or antibiotics produced by antagonistic strains. In numerous research experiments, the effectiveness of grapevine CG BCAs was restricted to certain opine-metabolizing tumorigenic $A$. vitis strains, which suggests that the sensitivity of various opinemetabolizing strains to biological control strains varies. Assessments of opine-metabolizing strain sensitivities to BCAs may foster understanding of action mechanisms of biological control strains. Deoxyribonucleic acid fingerprint comparison may also foster understanding of the genetic background of the diversity of Agrobacterium spp., which is essential for developing more effective BCAs. These may lead to the development of a BCA effective against each opine-metabolizing A. vitis strain type. In addition to efficacy against pathogenic strains, the limitation of biological control strains includes their persistence following deployment, including persistence in various soil types in vivo and in different rooting media. Endophytic colonization by BCAs and systemic movement throughout the plant are some other major limitations to their 
effective deployment. Nevertheless, the commercial success of $A$. radiobacter strain $\mathrm{K} 84$ and derivatives in controlling CG caused by A. tumefaciens confirms that this approach could also be used in grape CG management. Future research, of both previously tested and potential new isolates of BCAs, is necessary to: determine specific mode(s) of action, complete molecular and genetic understanding of biological control mechanisms, discover and develop new BCAs, field-test all effective biological control strains, and develop combinations of various BCAs capable of controlling grapevine CG disease regardless of the diversity of $A$. vitis strains.

Genetic mechanisms that trigger malignant cell growth and underlie CG formation are still not completely understood. Determination of currently unknown grapevine and Agrobacterium genes involved in the grape CG infection and genetic transformation processes and their exact roles would enhance understanding of the mechanisms of this disease. Furthermore, technological approaches in GM grapevine production, including the production of GM CG-resistant grapevines, must ensure that GM grapevines will have the same positive horticultural and quality characteristics as the non-GM plants.

Continued interest of the grape industry in CG-resistant grapevines is another factor critically necessary to achieve CG-resistant grapevine production. Virus-resistant GM grapevine production was accomplished with significant support from the grape and wine industry after unacceptable economic losses attributed to grapevine decline due to viral infections. Produced vines have been tested under experimental field conditions in different regions of the world; however, they are not available commercially. Therefore, to achieve CG-resistant grapevine production, close collaboration between scientific institutions and grape growers is pivotal. Improvements in the following areas may further foster the development of CG-resistant GM grapevine production: development of grape variety-specific regeneration methods to increase regeneration efficiency; reduction of the 5- to 10 year time requirement to generate testable GM grapevines; development of more rapid, accurate, and sensitive indexing systems to increase the reliability of presence determination of inserted genes and for the selective detection of tumorigenic and nontumorigenic Agrobacterium strains within grapevines; and development of a standardized evaluation system for CG resistance. In addition, successful commercial production of GM CG-resistant grapevines cannot be achieved without public acceptance.

Although biological control and genetic engineering were discussed separately, successful suppression of grapevine CG is likely to be achieved by incorporating and applying strategies from both those areas. This was mainly indicated in this review by describing GM BCAs and their applications. The importance of further collaboration among researchers from those fields and grape industry representatives would seem essential to further progress.

\section{Literature Cited}

Agrawal, N., P.V.N. Dasaradhi, A. Mohmmed, P. Malhotra, R.K. Bhatnagar, and S.K. Mukherjee. 2003. RNA interference: Biology, mechanism, and applications. Microbiol. Mol. Biol. Rev. 67:657-685.
Argun, N., M.T. Momol, S. Maden, E.A. Momol, C.L. Reid, H. Çelek, and T.J. Burr. 2002. Characterization of Agrobacterium vitis strains isolated from Turkish grape cultivars in the Central Anatolia region. Plant Dis. 86:162-166.

Bazzi, C., M. Alexandrova, E. Stefani, F. Anaclerio, and T.J. Burr. 1999. Biological control of Agrobacterium vitis using non-tumorigenic agrobacteria. Vitis 38:31-35.

Bell, C.R., G.A. Dickie, and J.W.Y.F. Chan. 1995. Variable response of bacteria isolated from grapevine xylem to control grape crown gall disease in planta. Am. J. Enol. Vitic. 46:499-508.

Burr, T.J., and B.H. Katz. 1984. Grapevine cuttings as potential sites of survival and means of dissemination of Agrobacterium tumefaciens. Plant Dis. 68:976-978.

Burr, T.J., and L. Otten. 1999. Crown gall of grape: Biology and disease management. Ann. Rev. Phytopathol. 37:53-80.

Burr, T.J., and C.L. Reid. 1994. Biological control of grape crown gall with non-tumorigenic Agrobacterium vitis strain F2/5. Am. J. Enol. Vitic. 45:213-219.

Burr, T.J., C. Bazzi, S. Süle, and L. Otten. 1998. Crown gall of grape: Biology of Agrobacterium vitis and the development of disease control strategies. Plant Dis. 82:1288-1297.

Burr, T.J., A.L. Bishop, B.H. Katz, L.M. Blanchard, and C. Bazzi. 1987. A root-specific decay of grapevine caused by Agrobacterium tumefaciens and A. radiobacter biovar 3. Phytopathology 77:1424-1427.

Burr, T.J., B.H. Katz, A.L. Bishop, C.A. Meyers, and V.L. Mittak. 1988. Effect of shoot age and tip culture propagation of grapes on systemic infestations by Agrobacterium tumefaciens biovar 3. Am. J. Enol. Vitic. 39:67-70.

Burr, T. J., L. Kovács, S. Süle, and E. Szegedi. 2003. Breeding for crown gall resistance: Traditional and molecular approaches. Acta Hort. 603:441-447.

Burr, T.J., C.L. Reid, C.E. Adams, and E.A. Momol. 1999. Characterization of Agrobacterium vitis strains isolated from feral Vitis riparia. Plant Dis. 83:102-107.

Burr, T.J., C.L. Reid, D.F. Splittstoesser, and M. Yoshimura. 1996. Effect of heat treatments on grape bud mortality and survival of Agrobacterium vitis in vitro and in dormant grape cuttings. Am. J. Enol. Vitic. 47:119-123.

Burr, T.J., C.L. Reid, E. Tagliati, C. Bazzi, and S. Süle. 1997. Biological control of grape crown gall by strain F2/5 is not associated with agrocin production or competition for attachment sites on grape cells. Am. Phytopathol. Soc. 87:706-711.

Chen, F., Y.B. Guo, J.H. Wang, J.Y. Li, and H.M. Wang. 2007. Biological control of grape crown gall by Rahnella aquatilis HX2. Plant Dis. 91:957-963.

Chen, F., J.Y. Li, Y.B. Guo, J.H. Wang, and H.M. Wang. 2009. Biological control of grapevine crown gall: Purification and partial characterization of an antibacterial substance produced by Rahnella aquatilis strain HX2. Eur. J. Plant Pathol. 124:427-437.

Chen, X.Y., and W.N. Xiang. 1986. A strain of Agrobacterium radiobacter inhibits growth and gall formation by biotype III strains of A. tumefaciens from grapevine. Acta Microbiol. Sin. 26:193-199.

Citovsky, V., D. Warnick, and P.C. Zambryski. 1994. Nuclear import of Agrobacterium VirD2 and VirE2 proteins in maize and tobacco. Proc. Natl. Acad. Sci. USA 91:3210-3214.

Cooksey, D.A., and L.W. Moore. 1982. Biological control of crown gall with an agrocin mutant of Agrobacterium radiobacter. Am. Phytopathol. Soc. 72:919-921.

Costacurta, A., and J. Vanderleyden. 1995. Synthesis of phytohormones by plant associated bacteria. Crit. Rev. Microbiol. 21:1-18.

Creasap, J.E., C.L. Reid, M.C. Goffinet, R. Aloni, C. Ullrich, and T.J. Burr. 2005. Effect of wound position, auxin and Agrobacterium 
vitis strain F2/5 on wound healing and crown gall in grapevine. Phytopathology 95:362-367.

De Cleene, M., and J. De Ley. 1976. The host range of crown gall. Bot. Rev. 42:389-466.

Dessaux, Y., A. Petit, S.K. Farrand, and P.J. Murphy. 1998. Opines and opine-like molecules involved in plant-Rhizobiaceae interactions. In The Rhizobiaceae: Molecular Biology of Model Plant-Associated Bacteria. H.P. Spaink et al. (eds.), pp. 173-197. Kluwer Academic, Dordrecht, Netherlands.

Donner, S.C., D.A. Jones, N.C. McClure, G.M. Rosewarne, M.E. Tate, A. Kerr, N.N. Fajardo, and B.G. Clare. 1993. Agrocin 434, a new plasmid encoded agrocin from the biocontrol Agrobacterium strains K84 and K1026, which inhibits biovar 2 agrobacteria. Physiol. Mol. Plant Pathol. 42:185-194.

Eastwell, K.C., P.L. Sholberg, and R.J. Sayler. 2006. Characterizing potential bacterial biocontrol agents for suppression of Rhizobium vitis, casual agent of crown gall disease in grapevines. Crop Prot. 25:1191-1200.

Ebinuma, H., E. Matsunaga, K. Yamada, and M. Yamakado. 1997. Transformation of hybrid aspen for resistance to crown gall disease. In Micropropagation, Genetic Engineering, and Molecular Biology of Populus. N.B. Klopfenstein et al. (eds.), pp. 161-164. USDA Forest Service, Rocky Mountain Forest and Range Experiment Station, Fort Collins, CO.

Escobar, M.A., E.L. Civerolo, K.R. Summerfelt, and A.M. Dandekar. 2001. RNAi-mediated oncogene silencing confers resistance to crown gall tumorigenesis. Proc. Natl. Acad. Sci. USA 98:13437-13442.

Farrand, S.K., J.E. Slota, J.S. Shim, and A. Kerr. 1985. Tn5 insertions in the agrocin 84 plasmid: The conjugal nature of pAgK84 and the locations of determinants for transfer and agrocin 84 production. Plasmid 13:106-117.

Fournier, P., P. de Ruffray, and L. Otten. 1994. Natural instability of Agrobacterium vitis Ti plasmid due to unusual duplication of a 2.3kb DNA fragment. Mol. Plant Microbe In. 7:164-172.

Gaudin, V., T. Vrain, and L. Jouanin. 1994. Bacterial genes modifying hormonal balances in plants. Plant Physiol. Biochem. 32:11-29.

Gelvin, S.B. 2003. Agrobacterium-mediated plant transformation: The biology behind the "gene-jockeying" tool. Microbiol. Mol. Biol. Rev. 67:16-37.

Hao, G., H. Zhang, D. Zheng, and T. J. Burr. 2005. luxR homolog avhR in Agrobacterium vitis affects the development of a grapespecific necrosis and a tobacco hypersensitive response. J. Bacteriol. 187:185-192.

Herlache, T.C., and E.W. Triplett. 2002. Expression of a crown gall biological control phenotype in an avirulent strain of Agrobacterium vitis by addition of the trifolitoxin production and resistance genes. BMC Biotechnol. 2:2.

Holden, M., S. Krasatanova, B. Xue, S. Pang, M. Sekiya, E.A. Momol, D. Gonsalves, and T.J. Burr. 2003. Genetic engineering of grape for resistance to crown gall. Acta Hort. 603:481-484.

Huss, B., B. Tinland, F. Paulus, B. Walter, and L. Otten. 1990. Functional analysis of a complex oncogene arrangement in biotype III Agrobacterium tumefaciens strains. Plant Mol. Biol. 14:173-186.

Kawaguchi, A., and K. Inoue. 2009. Grapevine crown gall caused by Rhizobium radiobacter (Ti) in Japan. J. Gen. Plant Pathol. 75:205-212.

Kawaguchi, A., K. Inoue, and Y. Ichinose. 2008. Biological control of crown gall of grapevine, rose, and tomato by nonpathogenic Agrobacterium vitis strain VAR03-1. Am. Phytopathol. Soc. 98:1218-1225.

Kawaguchi, A., K. Inoue, and H. Nasu. 2005. Inhibition of crown gall formation by Agrobacterium radiobacter biovar 3 strains isolated from grapevine. J. Gen. Plant Pathol. 71:422-430.

Kawaguchi, A., K. Inoue, and H. Nasu. 2007. Biological control of grapevine crown gall by nonpathogenic Agrobacterium vitis strain VAR03-1. J. Gen. Plant Pathol. 73:133-138.
Kerr, A. 1972. Biological control of crown gall: Seed inoculation. J. Appl. Microbiol. 35:493-497.

Kerr, A., and K. Htay. 1974. Biological control of crown gall through bacteriocin production. Physiol. Plant Pathol. 4:37-44.

Kerr, A., and C.G. Panagopoulos. 1977. Biotypes of Agrobacterium radiobacter var. tumefaciens and their biological control. Phytopathol. Z. 90:172-179.

Khmel, I.A., T.A. Sorokina, N.B. Lemanova, V.A. Lipasova, O.Z. Metlitski, T.V. Burdeinaya, and L.S. Chernin. 1998. Biological control of crown gall in grapevine and raspberry by two Pseudomonas spp. with a wide spectrum of antagonistic activity. Biocontrol Sci. Tech. 8:45-57.

Kikkert, J.R., J.R. Vidal, P.G. Wallace, S. Garcia-Zitter, W.F. Wilcox, D.M. Gadoury, R.C. Seem, T.J. Burr, C.L. Rosenfield, S. Samuelian, and B.I. Reisch. 2009. Disease resistance analyses of transgenic grapevines that contain endochitinase or antimicrobial peptide genes. Acta Hort. 827:379-384.

Kim, J.G., B.K. Park, S.U. Kim, D. Choi, B.H. Nahm, J.S. Moon, J.S. Reader, S.K. Farrand, and I. Hwang. 2006. Bases of biocontrol: Sequence predicts synthesis and mode of action of agrocin 84 , the Trojan horse antibiotic that controls crown gall. Proc. Natl. Acad. Sci. USA 103:8846-8851.

Kottek, M., J. Grieser, C. Beck, B. Rudolf, and F. Rubel. 2006. World map of the Köppen-Geiger climate classification updated. Meteorol. Z. 15:259-263.

Kovács, L., S. Fekete, H. Hou, and E. Szegedi. 2003. Silencing the expression of an Agrobacterium vitis oncogene in a model plant. Acta Hort. 603:519-526.

Krastanova, S.V., V. Balaji, M.R. Holden, M. Sekiya, B. Xue, E.A. Momol, and T.J. Burr. 2010. Resistance to crown gall disease in transgenic grapevine rootstocks containing truncated virE2 of Agrobacterium. Transgenic Res. 19:949-958.

Lacroix, B., M. Elbaum, V. Citovsky, and T. Tzfira. 2008. Intracellular transport of Agrobacterium T-DNA. In Agrobacterium: From Biology to Biotechnology. T. Tzfira and V. Citovsky (eds.), pp. 365-394. Springer, New York.

de Lajudie, P., E. Laurent-Fulele, A. Willems, U. Torck, R. Coopman, M.D. Collins, K. Kersters, D. Dreyfus, and M. Gillis. 1998. Description of Allorhizobium undicola gen. nov., sp. nov. for nitrogen-fixing bacteria efficiently nodulating Neptunia natans in Senegal. Int. J. Syst. Bacteriol. 48:1277-1290.

van Larebeke, N., G. Engler, M. Holsters, S. Van den Elsacker, I. Zaenen, R.A. Schilperoort, and J. Schell. 1974. Large plasmid in Agrobacterium tumefaciens essential for crown gall-inducing ability. Nature 252:169-170

Lee, H., J.L. Humann, J.S. Pitrak, J.T. Cuperus, T.D. Parks, C.A. Whistler, M.C. Mok, and L.W. Ream. 2003. Translation start sequences affect the efficiency of silencing of Agrobacterium tumefaciens T-DNA oncogenes. Plant Physiol. 133:966-977.

Lehoczky, J. 1968. Spread of Agrobacterium tumefaciens in the vessels of the grapevine after natural infection. Phytopathol. Z. 63:239-246.

Lehoczky, J. 1971. Further evidences concerning the systemic spreading of Agrobacterium tumefaciens in the vascular system of grapevines. Vitis 10:215-221.

Lehoczky, J. 1978. Root-system of the grapevine as a reservoir of Agrobacterium tumefaciens cells. In Proceedings of the Fourth International Conference on Plant Pathogenic Bacteria. Station de Pathologie Végétale et Phytobactériologie (ed.), pp. 239-243. Institut National de la Recherche Agronomique, Angers, Beaucouzé, France.

Lehoczky, J. 1989. Inoculation experiment on trellised grapevines with Agrobacterium tumefaciens for study of the process of crown gall disease. Acta Phytopathol. Entomol. Hung. 24:283-291. 
Li, J.Y., F. Chen, J.H. Wang, and H.M. Wang. 2005. Colonization of crown gall biocontrol agent - Agrobacterium vitis strain E26 on grapevine. Acta Phytopathol. Sin. 35:78-83.

Liang, Y.J., Y.B. Di, J.Y. Zhao, and D.Q. Ma. 1990a. Strain E26 of Agrobacterium radiobacter efficiently inhibits crown gall formation on grapevines. Chin. Sci. Bull. 35:1055-1056.

Liang, Y.J., J.Y. Zhao, and D.Q. Ma. 1990b. A biotype 3 strain of Agrobacterium radiobacter inhibits crown gall formation on grapevine. Acta Microbiol. Sin. 30:161-171.

Liang, Z., H. Wang, and J. Wang. 2001. Preliminary study on effectiveness and the stability of E26 on controlling crown gall disease. J. Chin. Agric. Univ. 6:91-95.

Matthysse, A.G. 2006. The genus Agrobacterium. Prokaryotes 5:91-114.

Moore, L.W., and G. Warren. 1979. Agrobacterium radiobacter strain 84 and biological control of crown gall. Ann. Rev. Phytopathol. 17:163-179.

Moriguchi, K., Y. Maeda, M. Satou, N.S. Hardayani, M. Kataoka, N. Tanaka, and K. Yoshida. 2001. The complete nucleotide sequence of a plant root-inducing ( $\mathrm{Ri}$ ) plasmid indicates its chimeric structure and evolutionary relationship between tumor-inducing (Ti) and symbiotic (Sym) plasmids in Rhizobiaceae. J. Mol. Biol. 307:771-784.

Mozsár, J., O. Viczián, and S. Süle. 1998. Agrobacterium-mediated genetic transformation of an interspecific grapevine. Vitis 37:127-130.

Morris, R.O. 1986. Genes specifying auxin and cytokinin biosynthesis in phytopathogens. Ann. Rev. Plant. Physiol. 37:509-538.

Nakano, M., Y. Hoshino, and M. Mii. 1994. Regeneration of transgenic plants of grapevine (Vitis vinifera L.) via Agrobacterium rhizogenesmediated transformation of embryogenic calli. J. Exp. Bot. 45:649-656.

Oláh, R., E. Szegedi, S. Ruthner, and J. Korbuly. 2003. Optimization of conditions for regeneration and genetic transformation of rootstock- and scion grape varieties. Acta Hort. 603:491-497.

Ophel, K., and A. Kerr. 1990. Agrobacterium vitis sp. nov. for strains of Agrobacterium biovar 3 from grapevines. Int. J. System. Bacteriol. 40:236-241.

Otten, L., P. de Ruffray, E.A. Momol, M.T. Momol, and T.J. Burr. 1996. Phylogenetic relationships between Agrobacterium vitis isolates and their Ti plasmids. Mol. Plant Microbe In. 9:782-786.

Otten, L., T.J. Burr, and E. Szegedi. 2008. Agrobacterium: A diseasecausing bacterium. In Agrobacterium: From Biology to Biotechnology. T. Tzfira and V. Citovsky (eds.), pp. 1-46. Springer, New York.

Paulus, F., B. Huss, G. Bonnard, M. Ridé, E. Szegedi, J. Tempé, A. Petit, and L. Otten. 1989. Molecular systematics of biotype III Ti plasmids of Agrobacterium tumefaciens. Mol. Plant Microbe In. 2:64-74.

Peñalver, R., B. Vicedo, and M.M. López. 2000. Use of the genetically engineered Agrobacterium strain K1026 for biological control of crown gall. Eur. J. Plant Pathol. 106:801-810.

Petersen, S.G., B.M. Stummann, P. Olesen, and K.W. Henningsen. 1989. Structure and function of root-inducing (Ri) plasmids and their relation to tumor-inducing (Ti) plasmids. Physiol. Plant. 77:427-435.

Petit, A., C. David, G.A. Dahl, J.G. Ellis, P. Guyon, F. Casse-Delbart, and J. Tempé. 1983. Further extension of the opine concept: Plasmids in Agrobacterium rhizogenes cooperate for opine degradation. Mol. Gen. Genet. 190:204-214.

Pinkerton, J.N., K.L. Ivors, M.L. Miller, and L.W. Moore. 2000. Effect of soil solarization and cover crops on populations of selected soil borne plant pathogens in western Oregon. Plant Dis. 84:952-960.

Pionnat, S., H. Keller, D. Hericher, A. Bettachini, Y. Dessaux, X. Nesme, and C. Poncet. 1999. Ti plasmids from Agrobacterium characterize rootstock clones that initiated a spread of crown gall disease in Mediterranean countries. Appl. Environ. Microbiol. 65:4197-4206.

Du Plessis, H.J., M.J. Hattingh, and H.J.J. van Vuuren. 1985. Biological control of crown gall in South Africa by Agrobacterium radiobacter strain K84. Plant Dis. 69:302-305.
Portier, P., M. Fischer-Le Saux, C. Mougel, C. Lerondelle, D. Chapulliot, J. Thioulouse, and X. Nesme. 2006. Identification of genomic species in Agrobacterium biovar 1 by AFLP genomic markers. Appl. Environ. Microbiol. 72:7123-7131.

Pu, X.A., and R.N. Goodman. 1993a. Effects of fumigation and biological control on infection of indexed crown gall free grape plants. Am. J. Enol. Vitic. 44:241-248.

Pu, X.A., and R.N. Goodman. 1993b. Tumor formation by Agrobacterium tumefaciens is suppressed by Agrobacterium radiobacter HLB-2 on grape plants. Am. J. Enol. Vitic. 44:249-254.

Robleto, E.A., J. Borneman, and E.W. Triplett. 1998. Effects of bacterial antibiotic production on rhizosphere microbial communities from a culture-independent perspective. Appl. Environ. Microbiol. 64:5020-5022.

Sands, P., and P. Galizzi. 2006. Documents in European Community Environmental Law. Cambridge University Press, Cambridge, UK.

Sawada, H., H. Ieki, H. Oyaizu, and S. Matsumoto. 1993. Proposal for rejection of Agrobacterium tumefaciens and revised descriptions for the genus Agrobacterium and for Agrobacterium radiobacter and Agrobacterium rhizogenes. Int. J. Syst. Bacteriol. 43:694-702.

Scorza, R., J.M. Cordts, D.J. Gray, D. Gonsalves, R.L. Emershad, and D.W. Ramming. 1996. Producing transgenic 'Thompson Seedless' grape (Vitis vinifera L.) plants. J. Am. Soc. Hort. Sci. 121:616-619.

Scupham, A.J., and E.W. Triplett. 2006. Determination of the amino acid residues required for the activity of the anti-rhizobial peptide antibiotic trifolitoxin. J. Appl. Microbiol. 100:500-507.

Staphorst, J.L., F.G.H. van Zyl, B.W. Strijdom, and Z.E. Groenewold. 1985. Agrocin-producing pathogenic and nonpathogenic biotype-3 pathogens. Current Microb. 12:45-52.

Stewart, E.L., and N.G. Wenner. 2004. Grapevine decline in Pennsylvania and New York. Wine East. 32:12-21, 51-53.

Süle, S., and T.J. Burr. 1998. The effect of resistance of rootstocks to crown gall (Agrobacterium spp.) on the susceptibility of scions in grape vine cultivars. Plant Pathol. 47:84-88.

Süle, S., J. Lehoczky, G. Jenser, P. Nagy, and T.J. Burr. 1995. Infection of grapevine roots by Agrobacterium vitis and Meloidogyne hapla. J. Phytopathol. 143:169-171.

Szegedi, E. 1995. A review of the use of thermotherapy in viticulture to eliminate pathogens and pests from propagating material. Pestic. Sci. 45:285-286.

Szegedi, E., and S. Bottka. 2002. Detection of Agrobacterium vitis by polymerase chain reaction in grapevine bleeding sap after isolation on a semiselective medium. Vitis 41:37-42.

Szegedi, E., and B.-né Dula. 2006. Az agrobaktériumos fertőzés kimutatása szőlőoltványokból. Növényvédelem 2:61-66.

Szegedi, E., and P. Kozma. 1984. Studies on the inheritance of resistance to crown gall disease of grapevine. Vitis 23:121-126.

Szegedi, E., and S. Süle. 2005. Agrobaktériumos fertőzéstől mentes szőlő szaporítóanyag előállítása. Növényvédelem 10:467-476.

Szegedi, E., S. Bottka, J. Mikulás, L. Otten, and S. Süle. 2005. Characterization of Agrobacterium tumefaciens strains isolated from grapevine. Vitis 44:49-54.

Szegedi, E., M. Czakó, L. Otten, and C. Koncz. 1988. Opines in crown gall tumors induced by biotype 3 isolates of Agrobacterium tumefaciens. Physiol. Mol. Plant Pathol. 32:237-247.

Szegedi, E., J. Korbuly, and I. Koleda. 1984. Crown gall resistance in East-Asian Vitis species and in their V. vinifera hybrids. Vitis 23:21-26.

Szegedi, E., S. Süle, and T.J. Burr. 1999. Agrobacterium vitis strain F2/5 contains tartrate and octopine utilization plasmids which do not encode functions for tumor inhibition on grapevine. J. Phytopathol. 147:665-669. 
Thomashow, M.F., S. Hugly, W.G. Buchholz, and L.S. Thomashow. 1986. Molecular basis for the auxin-independent phenotype of crown gall tumor tissues. Science 231:616-618.

Thomson, J.A. 1986. The potential for biological control of crown gall disease on grapevines. Trends Biotechnol. 4:219-224.

Torregrosa, L., P. Iocco, and M.R. Thomas. 2002. Influence of Agrobacterium strain, culture medium, and cultivar on the transformation efficiency of Vitis vinifera L. Am. J. Enol. Vitic. 53:183-190.

Vicedo, B., R. Peñalver, M.J. Asins, and M.M. López. 1993. Biological control of Agrobacterium tumefaciens, colonization, and pAgK84 transfer with Agrobacterium radiobacter $\mathrm{K} 84$ and the Tra ${ }^{-}$mutant strain K1026. Appl. Environ. Microbiol. 59:309-315.

Vidal, J.R., J.R. Kikkert, M.A. Malnoy, P.G. Wallace, J. Barnard, and B.I. Reisch. 2006. Evaluation of transgenic 'Chardonnay' (Vitis vinifera) containing magainin genes for resistance to crown gall and powdery mildew. Transgenic Res. 15:69-82.

Wang, H.M., H.X. Wang, T.B. Ng, and J.Y. Li. 2003. Purification and characterization of an antibacterial compound produced by Agrobacterium vitis strain E26 with activity against $A$. tumefaciens. Plant Pathol. 52:134-139.

Wang, Y.H., L.Q. Zhang, J.Y. Li, J.H. Wang, and H.M. Wang. 2008. The quorum-sensing system AvsR-AvsI regulates both long-chain and short-chain acyl-homoserine lactones in Agrobacterium vitis E26. Anton. Leeuwenhoek 93:267-273.

Webster, J., and J. Thomson. 1988. Genetic analysis of an Agrobacterium tumefaciens strain producing an agrocin active against biotype 3 pathogens. Mol. Gen. Genet. 214:142-147.

Webster, J., M.D. Santos, and J.A. Thomson. 1986. Agrocin-producing Agrobacterium tumefaciens strain active against grapevine isolates. Appl. Environ. Microbiol. 52:217-219.

Wei, Q., J.Y. Li, J.H. Wang, and H.M. Wang. 2009. Strain E26 of Agrobacterium vitis, a biological control agent of grapevine crown gall, does not contain virA and virG pathogenic determinants. J. Phytopathol. 157:657-665.
Willems, A. 2006. The taxonomy of rhizobia: an overview. Plant Soil 287:3-14.

Willems, A., and M.D. Collins. 1993. Phylogenetic analysis of rhizobia and agrobacteria based on 16S rRNA gene sequences. Int. J. Syst. Bacteriol. 43:305-313.

Wilson, C.L. 1997. Biological control and plant diseases-A new paradigm. J. Ind. Microbiol. Biotechnol. 19:158-159.

Xue, B., K.S. Ling, C.L. Reid, S. Krastanova, M. Sekiya, E.A. Momol, S. Süle, J. Mozsár, D. Gonsalves, and T.J. Burr. 1999. Transformation of five grape rootstocks with plant virus genes and a virE2 gene from Agrobacterium tumefaciens. In vitro Cell. Dev. Biol. Plant. 35:226-231.

Xu, X., and S.Q. Pan. 2000. An Agrobacterium catalase is a virulence factor involved in tumorigenesis. Mol. Microbiol. 35:407-414.

Xuemei, X., Y. Jifeng, C. Peimin, and G. Junmei. 1993. On a strain MI 15 of Agrobacterium radiobacter for the biological control of grapevine crown gall. Acta Phytopathol. Sin. 23:137-141.

Young, J.M., L.D. Kuykendall, E. Martínez-Romero, A. Kerr, and H. Sawada. 2001. A revision of Rhizobium Frank 1889, with an emended description of the genus, and the inclusion of all species of Agrobacterium Conn 1942 and Allorhizobium undicola de Lajudie et al. 1998 as new combinations: Rhizobium radiobacter, $R$. rhizogenes, $R$. rubi, R. undicola and R. vitis. Int. J. Syst. Evol. Microbiol. 51:89-103.

Zabadal, T.J., I.E. Dami, M.C. Goffinet, T.E. Martinson, and M.L. Chien. 2007. Winter injury to grapevines and methods of protection. Extension Bulletin E2930. Michigan State University, East Lansing.

Zheng, D., H. Zhang, S. Carle, G. Hao, M.R. Holden, and T.J. Burr. 2003. A luxR homolog, aviR, in Agrobacterium vitis is associated with induction of necrosis on grape and a hypersensitive response on tobacco. Mol. Plant Microbe In. 16:650-658.

Zupan, J.R., and P.C. Zambryski. 1995. Transfer of T-DNA from Agrobacterium to the plant cell. Plant Physiol. 107:1041-1047. 